\title{
Correction to: Use of an Integrated Pan-Cancer Oncology Enrichment Next-Generation Sequencing Assay to Measure Tumour Mutational Burden and Detect Clinically Actionable Variants
}

\author{
Valerie Pestinger ${ }^{1} \cdot$ Matthew Smith ${ }^{2}$. Toju Sillo ${ }^{1}$. John M. Findlay ${ }^{3}$. Jean-Francois Laes ${ }^{4}$. Gerald Martin ${ }^{5}$. \\ Gary Middleton $^{6} \cdot$ Phillipe Taniere $^{2} \cdot$ Andrew D. Beggs $^{1,2}$ (I)
}

Published online: 22 June 2020

(c) The Author(s) 2020

\section{Correction to: \\ Molecular Diagnosis \& Therapy (2020) 24:339-349 \\ https://doi.org/10.1007/s40291-020-00462-x}

This article was originally published under a [CC BY NC 4.0] license, but has now been made available under a Creative Commons Attribution 4.0 International License (https:// creativecommons.org/licenses/by/4.0/), which permits use, sharing, adaptation, distribution and reproduction in any medium or format, as long as you give appropriate credit to the original author(s) and the source, provide a link to the Creative Commons licence, and indicate if changes were made. The PDF and HTML versions of the paper have been modified accordingly.
Open Access This article is licensed under a Creative Commons Attribution 4.0 International License, which permits use, sharing, adaptation, distribution and reproduction in any medium or format, as long as you give appropriate credit to the original author(s) and the source, provide a link to the Creative Commons licence, and indicate if changes were made. The images or other third party material in this article are included in the article's Creative Commons licence, unless indicated otherwise in a credit line to the material. If material is not included in the article's Creative Commons licence and your intended use is not permitted by statutory regulation or exceeds the permitted use, you will need to obtain permission directly from the copyright holder. To view a copy of this licence, visit http://creativecommons.org/licenses/by/4.0/.

The original article can be found online at https://doi.org/10.1007/ s40291-020-00462-x.

Andrew D. Beggs

a.beggs@bham.ac.uk

1 Surgical Research Laboratory, Institute of Cancer and Genomic Sciences, University of Birmingham, Vincent Drive, Birmingham B15 2TT, UK

2 Queen Elizabeth Hospital Birmingham, Birmingham, UK

3 Northern Devon Healthcare NHS Trust, Barnstaple, UK

4 OncoDNA, Gosselies, Belgium

5 PierianDx, St. Louis, MO, USA

6 Institute of Immunology and Immunotherapy, University of Birmingham, Birmingham, UK 